\title{
A novel approach for laparoscopic retrieval of dermoid cyst
}

\author{
Nitin H. Shah, Aditi V. Joshi*, Sunita Mourya
}

Department of Obstetrics and Gynecology, Vardann Multi speciality Hospital, Mumbai, Maharashtra, India

Received: 15 December 2018

Accepted: 11 January 2019

\section{*Correspondence:}

Dr. Aditi V. Joshi,

E-mail: avj111@gmail.com

Copyright: (c) the author(s), publisher and licensee Medip Academy. This is an open-access article distributed under the terms of the Creative Commons Attribution Non-Commercial License, which permits unrestricted non-commercial use, distribution, and reproduction in any medium, provided the original work is properly cited.

\begin{abstract}
A dermoid cyst is a germ cell tumour, benign in nature and common in young women under the age of 30 . They are usually asymptomatic and often detected incidentally on imaging. Resection of the cyst is important owing to complications like torsion or malignancy. Laparoscopic surgery is the modality of choice in today's era. However, rupture of the cyst during laparoscopic retrieval is any surgeon's nightmare. Hence, good surgical skill and a reliable method of retrieval are of prime importance here. Authors present a novel method of dermoid extraction done laparoscopically with a sterile urine collection (urobag) bag. This is an easy and simple method which decreases the rate of spillage owing to the strength of the bag.
\end{abstract}

Keywords: Dermoid cyst, Laparoscopic retrieval bags, Urobag bag

\section{INTRODUCTION}

Dermoid cysts also known as mature cystic teratomas are the most common ovarian tumours encountered in the reproductive age group. They comprise almost $70 \%$ of the benign tumours noted in women below the age of 30 years and $50 \%$ of paediatric ovarian tumours. ${ }^{1,2}$ They are mostly unilateral, however in $10-15 \%$ cases the cysts maybe bilateral. ${ }^{3}$ Most patients are asymptomatic and are diagnosed to have the cysts on routine imaging. The sensitivity of ultrasound imaging in detecting dermoid cysts is around 85\%.4 Laparoscopic management has many advantages over laparotomy and is the preferred approach today. However, laparoscopy has its own set of challenges with spillage of cyst contents being a prime concern owing to its potential to lead to complications like chemical peritonitis. ${ }^{5}$

\section{CASE REPORT}

A 28-year-old, nulligravida married for 2 years presented with symptoms of vague pain in abdomen. No other associated symptoms were present. Her menstrual cycle was regular.

On examination vital signs were normal. Cardiovascular and respiratory system examination was within normal limit. On per abdomen examination, abdomen was soft and there was no guarding, rigidity or tenderness. On per vaginum examination, uterus was normal size, retroverted and there was minimal fullness in right adnexa. Her laboratory investigations were within normal limits.

Ultrasound examination revealed a complex cyst of around $4 \mathrm{~cm}$ in right adnexa suggestive of dermoid cyst. Her blood investigations were within normal limits, tumour markers were normal. She was posted for a laparoscopic cystectomy.

Three ports were introduced, the primary port $10 \mathrm{~mm}$ was supraumbilical and two $5 \mathrm{~mm}$ secondary ports on the left side. Intraoperatively, an approximately $4 \mathrm{~cm}$ complex cyst was noted in the right adnexa. Uterus and contralateral ovary were normal. The cyst wall was 
peeled off and the cyst removed en-mass (Figure 1 and 2).

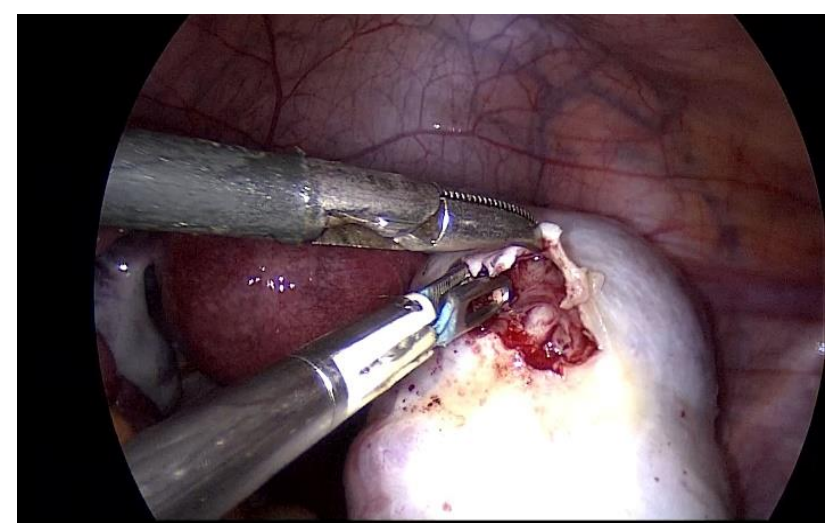

Figure 1: Excision of the right dermoid cyst.

The challenge of laparoscopic cystectomy in complex ovarian cyst lies in retrieving the cysts intact. Surgical gloves are a common method employed to remove the cyst from the abdomen.

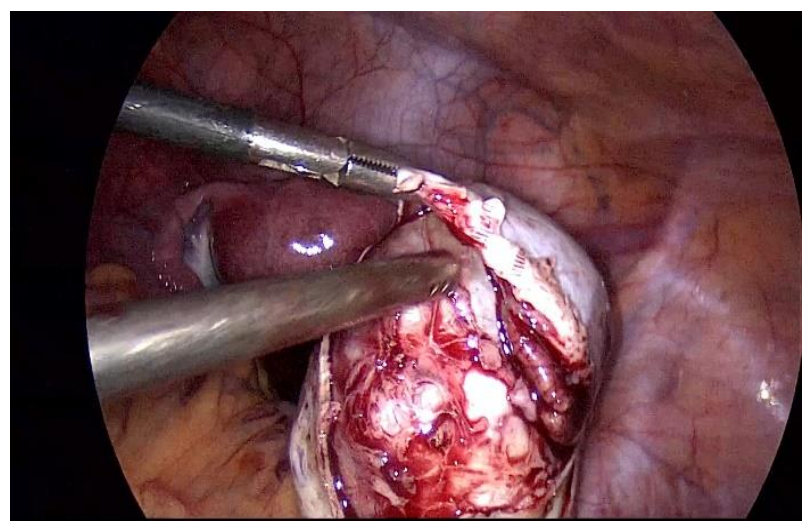

Figure 2: Enucleation and removal of the dermoid enmass.

However, often the glove may give way during cyst retrieval leading to intraperitoneal spillage of the cyst contents.

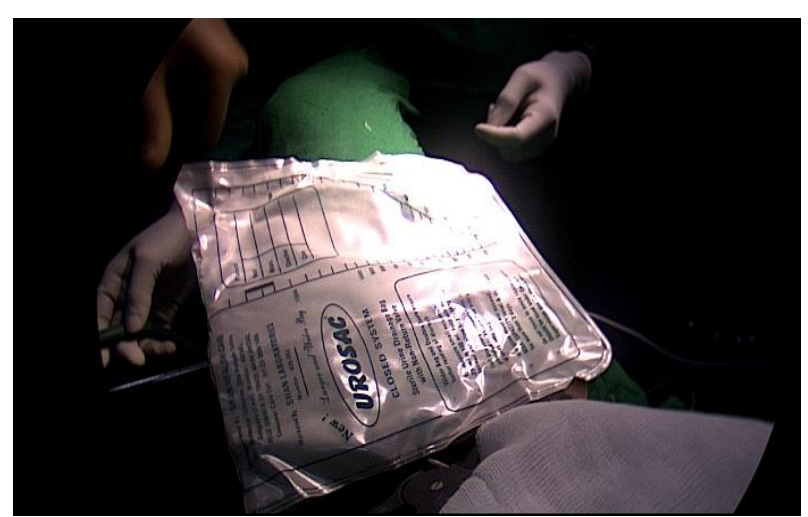

Figure 3: Insertion of the suction cannula into the urine collection bag (urobag).
In order to overcome this difficulty, authors decided to adopt a novel method of cyst retrieval with a sterile urine collection (urobag) bag. The major challenge was to introduce the bag in the abdomen. The urobag bag was opened from the upper end in its entirety so as to enable complete access from one end. The diameter of the lower secondary port was increased to $10 \mathrm{~mm}$ and the suction cannula with the urobag was introduced easily. The suction cannula was introduced into the bag from the open end and the bag was rolled onto the cannula so as to reduce the diameter and enable easy entry into the abdomen (Figure 3 and 4).

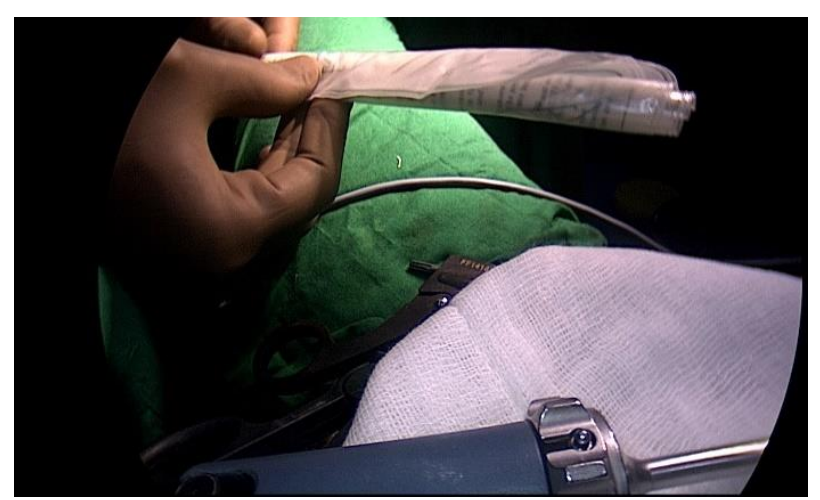

Figure 4: Rolling of the urobag bag around the suction cannula to facilitate easy entry into the abdomen via the accessory port.

The cyst was put into the urobag (Figure 5) and aspiration with morcellation was incorporated for easy retrieval, the presence of sebaceous material and tufts of hair suggested the diagnosis of dermoid cyst.

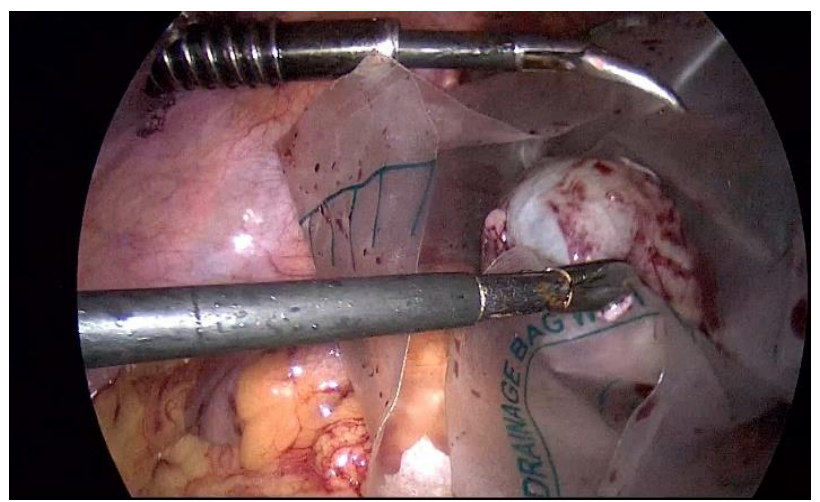

Figure 5: Specimen being inserted into the urobag bag that acts as the endobag in this case.

The bag with its contents were then retrieved from the trocar sleeve of the lower secondary port. The urobag provides better strength over the surgical gloves, thus ensuring no spillage of contents while rupturing the cyst.

\section{DISCUSSION}

Dermoid cysts are the most common ovarian tumour encountered in young women. They contain hair, 
sebaceous glands, epidermis etc. arising from residual embryonic tissue. They are indolent in nature but can undergo complications like torsion, rupture or malignant transformation. Hence, surgical excision of the cyst is important. The advent of minimal access surgery has made laparoscopy as the modality of choice. The spillage of the cyst contents during laparoscopic retrieval is one of the most dreaded events. It may lead to serious complications like intraperitoneal dissemination of malignant cells or peritonitis. ${ }^{6}$ Chemical peritonitis can occur due spillage of the cyst contents which can lead to dense intraperitoneal adhesions. ${ }^{7}$ Although peritonitis due to rupture of the dermoid cyst is a rare phenomenon, one must be aware of the same. If spillage of contents occur, a thorough copious lavage is critical. ${ }^{8}$

Laparoscopic retrieval of the specimen needs skill and expertise. There are studies which have reported a higher incidence of spillage with laparoscopy than laparotomy. However, the associated morbidities are also higher with a conventional laparotomy method. ${ }^{9}$ Hence laparoscopic surgeons need to be careful and vigilant will extracting the specimen from the abdominal cavity.

Laparoscopic specimen retrieval bags became popular with the advent of hazards of mechanical morcellation for uterine leiomyoma. These bags were also utilized for removal of other adnexal masses without spillage of contents. ${ }^{10}$ Endobag is a useful polyethylene bag first used in the United States for specimen retrieval. These are mostly manually opening. However, with the latest advances, there are automatically opening bags available as well. Currently available endobags come in various diameters, usually a $10 \mathrm{~cm}$ diameter bag is utilized for a $10 \mathrm{~mm}$ port. In developing countries like India, widespread use of endobag has limitations owing to the cost factor. There have been reports of use of other options over endobag like surgical gloves which are cost effective and also easily available. ${ }^{11}$ However due to the poor tensile strength of the gloves, they may tear during the process of morcellation leading to spread of the cyst contents intraperitoneally.

Authors adopted the use of a sterile urine bag (urobag) for specimen retrieval in this case. It is a cost effective alternative and also easy to deploy into the peritoneal cavity. In addition, the urobag has a better ability to withstand mechanical morcellation without causing spillage.

\section{CONCLUSION}

The accidental spillage of the contents of the dermoid cyst while retrieval is every surgeon's nightmare. The use of a sterile urobag for the retrieval of dermoid cyst can serve as an effective and inexpensive alternative over other methods.

Funding: No funding sources

Conflict of interest: None declared

Ethical approval: Not required

\section{REFERENCES}

1. Ayhan A, Bukulmez O, Genc C, Karamursel BS, Ayhan A. Mature cystic teratomas of the ovary: case series from one institution over 34 years. Europ J Obstet Gynecol Reprod Biol. 2000;88(2):153-7.

2. Templeman CL, Fallat ME, Lam AM, Perlman SE, Hertweck SP, O'connor DM. Managing mature cystic teratomas of the ovary. Obstet Gynecol Survey. 2000;55(12):738-45.

3. Al-Fozan H, Glassman J, Caspi B, Appelman Z, Tulandi T. La- teral distribution of ovarian dermoid cyst. J Am Ass Gynecol Laparosc. 2003;10:489-90.

4. Patel MD, Feldstein VA, Lipson SD, Chen DC, Filly RA. Cystic teratomas of the ovary: diagnostic value of sonography. AJR Am J Roentgenol. 1998;171(4):1061-5.

5. Clement D, Barranger E, Benchimol Y, Uzan S. Chemical peritonitis: a rare complication of an iatrogenic ovarian dermoid cyst rupture. Surg Endosc. 2003;17(4):658.

6. Mayer C, Miller DM, Ehlen TG. Peritoneal implantation of squamous cell carcinoma following rupture of a dermoid cyst during laparoscopic removal. Gynecol Oncol. 2002;84:180-3.

7. Esmaeili M, Shahbazi S, Seylani K, Nazari N. Ovarian dermoid cyst and neuromuscular manifestation. Nurs Pract Today. 2015;2(4):171-3.

8. Tarcoveanu E, Vasilescu A, Georgescu S, Danila N, Bradea C, Lupascu C, et al. Laparoscopic approach to ovarian dermoid cysts. Chirurgia (Bucur). 2012;107(4):461-8.

9. Laberge PY, Levesque S. Short-term morbidity and long-term recurrence rate of ovarian dermoid cysts treated by laparoscopy versus laparotomy. J Obstet Gynaecol Can. 2006;28(9):789-3.

10. Smorgick N. Laparoscopic specimen retrieval bags. J Obstet Gynecol India. 2014;64(5):370-2.

11. Yao CC, Wong HH, Yang CC, Lin CS, Liu JC. Liberal use of a bag made from a surgical glove during laparoscopic surgery for specimens retrieval. Surg Laparosc Endosc Percutan Techniques. 2000;10(4):261-3.

Cite this article as: Shah NH, Joshi AV, Mourya S. A novel approach for laparoscopic retrieval of dermoid cyst. Int J Reprod Contracept Obstet Gynecol 2019;8:744-6. 